\title{
PPM Desa Tungkal I Dalam Pengembangan Produk Berbasis Kelapa Pada Kawasan Lindung Hutan Mangrove
}

\author{
Bambang Irawan, Rike Puspitasari Tamin, Asrizal Paiman, Eva Achmad, Marwoto \\ Fakultas Kehutanan Universitas Jambi \\ Kampus Pinang Masak Jalan Raya Jambi-Ma.Bulian KM. 15 Mendalo Indah \\ irawanbam@yahoo.com
}

\begin{abstract}
Abstrak: Kabupaten Tanjung Jabung Barat memiliki tanaman kelapa dengan luasan 38.546 Ha dengan produktivitas sebesar 50.494 ton dan produktivitas perhektarnya sebesar 1,2ton/ha (Statistik Perkebunan, 2013 dalam Kemala, 2015). Salah satu sentra penghasil kelapa di Kabupaten Tanjung Jabung Barat adalah di Kecamatan Tungkal Ilir Desa Tungkal I Dusun Bahagia. Di Desa Tungkal I khususnya di Dusun Bahagia. Buah kelapa selama ini hanya diproduksi menjadi kopra dan tempurung dijadikan arang. Sejak tahun 2016, tim pengabdian Fakultas Kehutanan Universitas Jambi telah membina anggota kelompok tani Dusun Bahagia dalam pengelolaan kelapa mulai dari buah kelapa dijadikan Virgin Coconut Oil (VCO), sabut kelapa dijadikan cocopeat dan tempurung kelapa dijadikan briket arang. Tim pengabdian masih melihat ada potensi limbah kelapa yang belum termanfaatkan dengan baik yaitu air kelapa. Air kelapa selama ini hanya dibuang begitu saja tanpa diolah menjadi sesuatu yang bernilai ekonomis. Untuk itu tim pengabdian berinisiatif di 2018 untuk memecahkan masalah mitra tersebut yaitu pengolahan air kelapa menjadi asam cuka dan nata de coco. Dari hasil kegiatan penyuluhan dan demonstrasi pengolahan air kelapa menjadi asam cuka, didapatkan hasil bahwa kelompok tani bakau lestari dan kelompok tani wanita RT.08 Dusun Bahagia Desa Tungkal I sangat antusias terhadap materi pengabdian yang diberikan yaitu pengolahan air kelapa menjadi asam cuka karena selama ini air kelapa di Dusun Bahagia yang melimpah selalu dibuang. Anggota kelompok tani telah memahami dan merasa yakin bahwa mereka dapat mempraktekkan sendiri cara pengolahan air kelapa menjadi asam cuka.
\end{abstract}

\section{PENDAHULUAN}

\subsection{Analisis Situasi}

Kabupaten Tanjung Jabung Barat mempunyai luas areal perkebunan seluas 171.333,6 Ha yang meliputi beberapa komoditi perkebunan yaitu kelapa sawit, karet, kelapa, kopi dan pinang (Bangun, 2017). Untuk komoditi kelapa sendiri Kabupaten Tanjung Jabung Barat memiliki luas tanaman menghasilkan seluas 38.546 Ha dengan produktivitas sebesar 50.494 ton dan produktivitas perhektarnya sebesar 1,2ton/ha (Statistik Perkebunan, 2013 dalam Kemala, 2015). Salah satu sentra pengahasil kelapa di Kabupaten Tanjung Jabung Barat adalah di Kecamatan Tungkal Ilir Desa Tungkal I Dusun Bahagia. Di Desa Tungkal I khususnya di Dusun Bahagia, sebagaian besar masyarakatnya berprofesi sebagai petani kelapa hal ini dapat dilihat disepanjang kanan kiri jalannya banyak kita kebun kelapa (Gambar 1.A) dimana buah kelapa tersebut umumnya diolah oleh petani untuk dijadikan kopra (Gambar 1.B). 


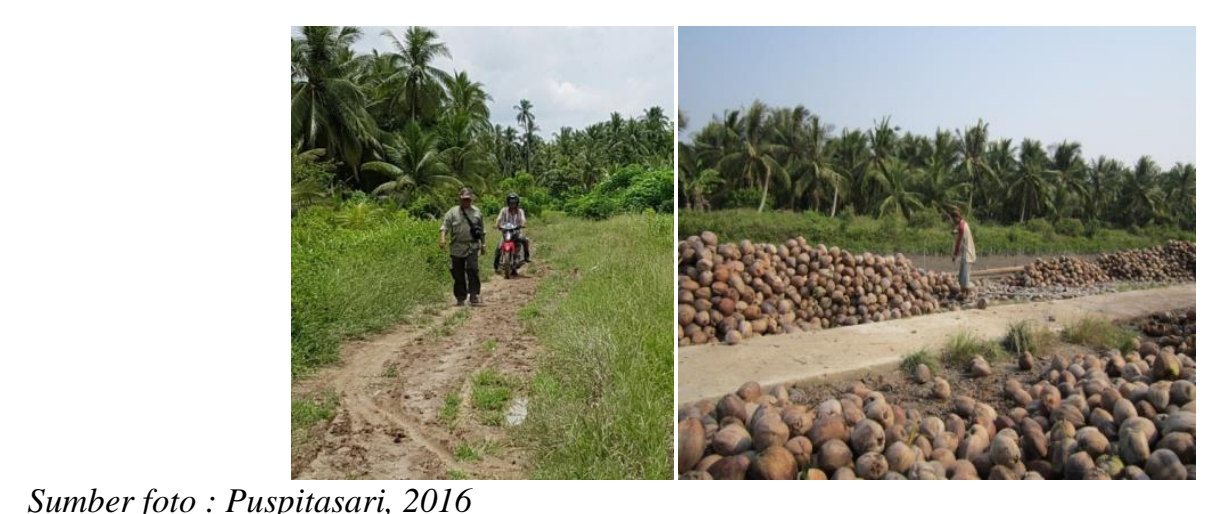

A

B

Gambar 1. Potensi kelapa di Dusun Bahagia Desa Tungkal I

Salah satu limbah kelapa yang masih belum dimanfaatkan yaitu air kelapa. Untuk itu tim pengabdian bina desa Fakultas Kehutanan Universitas Jambi berinisiatif melalui kegiatan bina desa 2018 untuk mmberikan pelatihan pengolahan limbah air kelapa menjadi asam cuka dan nata de coco sehingga dapat memberikan kegiatan tambahan kepada mitra untuk menambah pendapatan sehingga dapat meningkatkan perekonomian keluarga khususnya dan perekonomian masyarakat Desa Tungkal I.

\subsection{Permasalahan Mitra}

Besarnya potensi buah kelapa yang terdapat di Desa Tungkal I yang selama ini hanya diolah menjadi kopra dan batok arang membuat tim bina desa Fakultas Kehutanan Universitas Jambi untuk memberikan pelatihan kepada mitra dalam mengolah produk turunan buah kelapa lainnya. Produk yang dihasilkan tersebut berupa VCO di tahun 2016 serta briket arang dan cocopeat di tahun 2017. Setelah daging buah kelapa dan limbah serbuk arang tempurung serta sabut diolah, muncul permasalahan bahwa selama ini air kelapa tidak termanfaatkan dengan baik. Untuk itu tim bina desa Fakultas Kehutanan Universitas Jambi di tahun 2018 ini akan memberikan pelatihan pengolahan air kelapa menjadi asam cuka dan nata de coco sehingga semua produk kelapa yaitu daging buah, serbuk arang tempurung, sabut kelapa, dan air kelapa dapat termanfaatkan secara penuh dan optimal.

Produk yang dihasilkan oleh mitra selama ini dipasarkan melalui koperasi Sylva Bahagia Binaan Fakultas Kehutanan Universitas Jambi. Mitra belum dapat mengemas dengan baik produk yang dihasilkan dan perlu dilakukan kegiatan pemasaran yang lebih luas sehingga lebih banyak masyarakat mengenal produk yang dihasilkan dan memperluas area pemasaran. Dengan demikan diharapkan seluruh kegiatan bina desa ini dapat meningkatkan pendapatan masyarakat Desa Tungkal I yang hidup di kawasan lindung hutan mangrove.

\section{SOLUSI YANG DITAWARKAN}

Berdasarkan permasalahan mitra yang telah diuraikan di atas, tim pengabdian kepada masyarakat memberikan beberapa solusi terkait yang dapat menyelesaikan permasalahn tersebut, antara lain :

1. Memberikan penyuluhan kepada kedua mitra tentang manfaat lain limbah buah kelapa yaitu air kelapa untuk diolah menjadi asam cuka dan nata de coco.

2. Memberikan demonstrasi dan pelatihan kepada kedua mitra tentang teknologi sederhana yang bisa digunakan untuk pengolahan air kelapa menjadi asam cuka dan nata de coco. 
3. Memberikan pendampingan dalam pemasaran asam cuka dan nata de coco. yang dihasilkan oleh kedua mitra.

4. Meningkatkan pengetahuan masyarakat khususnya kepada kedua mitra dari segi aspek pemasaran produk-produk yang telah dibuat di tahun 2016 dan 2017 dalam skala industri rumah tangga.

Dari beberapa solusi yang ditawarkan kepada mitra, tim pengabdian kepada masyarakat Fakultas kehutanan memiliki harapan besar bahwa mitra dapat menghasilkan kedua produk tersebut dan mampu secara mandiri melalui koperasi Sylva Bahagia dalam kegiatan pemasaran dalam skala luas sehingga dapat meningkatkan pendapatan mitra, sehingga mitra yang bertempat tinggal langsung berbatasan dengan hutan mangrove Pangkal Babu dapat terus menjaga kelestarian hutan mangrove karena mereka tidak perlu mengambil hasil hutan mangrove tersebut untuk memenuhi kebutuhan hidup mereka sehari-hari.

\section{METODE PELAKSANAAN}

\subsection{Tempat dan Waktu}

Kegiatan pengabdian kepada masyarakat ini dilaksanakan di Dusun Bahagia Desa Tungkal I Kecamatan Tungkal Ilir Kabupaten Tanjung Jabung Barat dengan 2 (dua) mitra yang terlibat yaitu kelompok tani bakau lestari dan kelompok tani wanita Dusun Bahagia RT.08. Waktu kegiatan dimulai sejak persiapan selama 6 (enam) bulan dari bulan April Oktober 2018.

\subsection{Bahan dan Alat}

Bahan yang digunakan dalam penelitian ini antara lain air kelapa tua, ragi roti (Saccharomyces cerevisiae), $\left(\mathrm{NH}_{4}\right)_{2} \mathrm{SO}_{3}$, bakteri starter Acetobacter xylinum, asam cuka, gula pasir, urea, dan kertas $\mathrm{pH}$. Sedangkan Alat yang digunakan dalam penelitian ini yaitu kamera, nampan plastik, baskom, drigen, corong, kompor gas, toples, saringan, wajan, pangaduk kayu, air suling, panci, koran, tali rafia, pisau, pulpen, note book, in fokus, cup sealer manual (alat press gelas plastik), gelas plastik, pisau, ceret stainless kain lap, dan botol kemasan plastik.

\subsection{Prosedur Kegiatan}

\section{Penyuluhan}

Prosedur kegiatan pengabdian ini terdiri dari beberapa tahapan kegiatan, antara lain :

Kegiatan penyuluhan ini terdiri dari dua tahap kegiatan penyuluhan yaitu pertama kali dilakukan di awal kegiatan dan diakhir kegiatan pengabdian. Kegiatan penyuluahn pertama dilakukan bertujuan untuk memberikan pemahaman akan manfaat yang bisa diperoleh dari pengolahan limbah kelapa berupa air kelapa menggunakan teknologi sederhana untuk dijadikan asam cuka dannata de coco. Penyuluhan dilakukan dengan mempresentasikan materi penyuluhan yang dibuat dalam bentuk power point kepada kedua mitra secara bersamaan. Setelah presentasi dilakukan diskusi dua arah secara informal dan kekeluargaan guna menciptakan sambung rasa atau keakraban antara dua mitra dengan tim pengabdian. Di kegiatan penyuluhan ini juga akan dijelaskan, bagaimana prospek pemasaran dari produk asam cuka dannata de coco yang akan dihasilkan oleh kedua mitra.

Kegiatan penyuluhan kedua dilakukan di akhir kegiatan sebelum dilakukan evaluasi. Kegiatan penyuluhan kedua bertujuan untuk memberikan pemahaman untuk meningkatkan 
pengetahuan masyarakat dalam aspek pengemasan dan pemasaran produk-produk yang telah dihasilkan dari kegiatan bina desa Fakultas Kehutanan Universitas Jambi (VCO, briket arang, cocopeat, asam cuka dannata de coco)dalam upaya meningkatkan perekonomian anggota keluarga mitra pada khususnya dan masyarakat Dusun Bahagia pada umumnya sehingga masyarakat tidak harus mengambil hasil hutan mangrove yang berbatasan langsung dengan tempat tinggal mereka. Dalam Kegiatan penyuluhan kedua ini akan diberikan pemahaman dan petunjuk cara pengemasan produk semenarik mungkin guna meningkatkan daya tarik pembeli. Masyarakat akan diajarkan cara pemasaran langsung maupun secara online dimana tim bina desa Fakultas Kehutanan Universitas Jambi akan mengembangkan website dalam menjangkau pasar digital.

\section{Demontrasi dan Pelatihan}

Setelah kegiatan penyuluhan dilakukan, kegiatan selanjutnya adalah demonstrasi dan pelatihan. Kegiatan demonstrasi dan pelatihan dilakukan sebanyak dua kali kegiatan yang terdiri atas:

\subsection{Demonstrasi dan Pelatihan Pembuatan Asam Cuka 2.2. Demonstrasi dan Pelatihan Pembuatan Nata de Coco}

\subsection{Evaluasi Kegiatan}

Setelah kegiatan penyuluhan, demonstrasi dan pelatihan selesai dilakukan, kedua mitra diminta untuk melakukan pembuatan asam cuka dan nata de coco secara mandiri. Setelah itu, tim pengabdian kepada masyarakat akan melakukan evaluasi terhadap kedua produk yang dihasilkan oleh secara mandiri kedua mitra. Dalam kegaiatan evaluasi ini akan dilihat bagaimana tingkat keberhasilan pembuatan kedua produk oleh kedua mitra, hambatan dan kendala yang dialami oleh kedua mitra, kuantitas dan kualitas produk yang dihasilkan oleh kedua mitra. Di dalam evaluasi kegiatan juga akan dinilai keberhasilan bagaimana pengemasan yang telah dilakukan oleh mitra untuk meningkatkan nilai penjualan dan bagaimana keberhasilan pembuatan website di dalam meningkatkan penjualan produk-produk yang dihasilkan mitra mulai tahun 2016-2018 (VCO, briket arang, cocopeat, nata de coco, dan asam cuka).

\section{HASIL DAN LUARAN YANG DICAPAI}

Kegiatan pengabdian pada masyarakat ini terbagi dalam beberapa kegiatan yaitu : pengurusan izin kegiatan pengabdian pada masyarakat, penyuluhan dan demontrasi pembuatan asam cuka dari air kelapa, penyuluhan dan demontrasi pembuatan nata de coco dari air kelapa, evaluasi kepada anggota kelompok tani terhadap pemahaman dan peningkatan ketrampilan dalam pembuatan asam cuka dari air kelapa, evaluasi kepada anggota kelompok tani terhadap pemahaman dan peningkatan ketrampilan dalam pembuatan nata de coco dari air kelapa, kegiatan penyuluhan pemahaman untuk meningkatkan pengetahuan masyarakat dalam aspek pengemasan dan pemasaran produk-produk yang telah dihasilkan dari kegiatan bina desa Fakultas Kehutanan Universitas Jambi (VCO, briket arang, cocopeat, asam cuka dan nata de coco), dan evaluasi serta monitoring dari seluruh kegiatan yang dilakukan. 
Dalam kegiatan pengabdian pada masyarakat di Tahun 2018 ini yang dilakukan tim pengabdian pada masyarakat menemui beberapa hambatan yaitu : sulitnya mengatur jadwal kegiatan antara tim pengabdian pada masyarakat dengan anggota kelompok tani dikarenaka kesibukan tim pengabdian pada masyarakat terkait kewajiban pekerjaan yang lainnya dan waktu dari anggota kelompok tani karena sebagian besar anggota kelompok tani saat pagi hari hingga sore ini berada di kebun. Cara mengatasi permasalahan ini, tim pengabdian selalu berkomunikasi dengan ketua kelompok tani Bakau Lestari dan Kelompok Tani Wanita RT. 08 Dusun Bahagia melalui telepon, meskipun terkadang hal ini juga sulit dilakukan terkait susahnya/tidak adanya sinyal di Dusun Bahagia Desa Tungkal I tersebut.

Selain hambatan yang telah dijelaskan di atas, terdapat hambatan lainnya yaitu ketika tim akan melakukan kegiatan pengabdian di lokasi hujan maka tim mengalami kesulitan untuk masuk ke Dusun Bahagia Desa Tungkal I terkait jalan yang kurang baik saat terjadi hujan. Untuk mengatasi hal tersebut tim memilih alternatif perjalanan melalui laut dengan menggunakan speedboats.

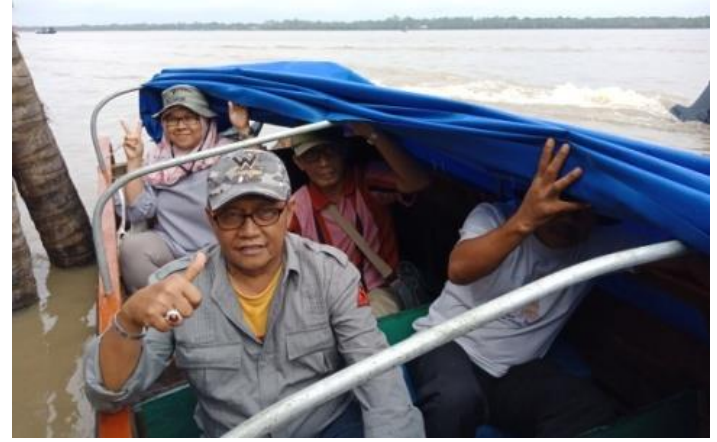

Gambar 2. Perjalanan Tim Pengabdian Pada Masyarakat Melalui Jalur Laut

Sampai saat ini kegiatan yang telah dilakukan tim pengabdian kepada masyarakat adalah kegiatan koordinasi dan pengurusan izin kepada ketua kelompok tani terkait kegiatan yang akan dilakukan. Pada kegiatan ini dilakukan juga serah terima sebagian alat-alat yang akan digunakan di dalam kegiatan pengabdian pada masyarakat.

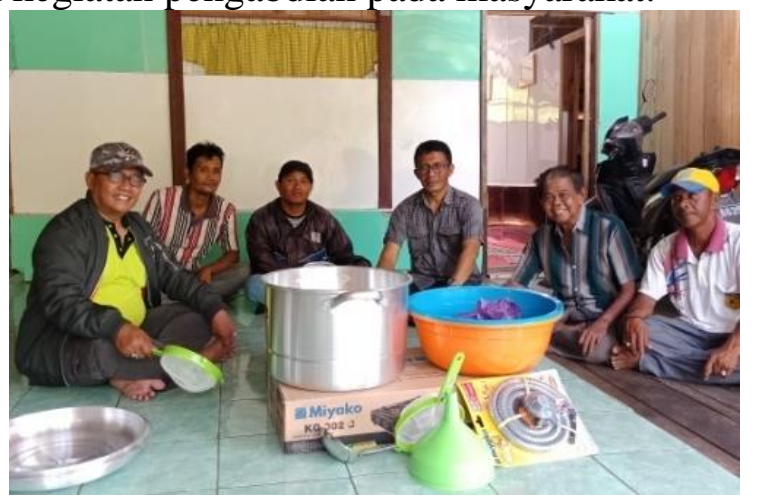

Gambar 3. Berfoto Bersama Ketua Kelompok Tani Saat Kegiatan Koordinasi dan Pengurusan Izin

Kegiatan berikutnya adalah penyuluhan dan demontrasi pembuatan asam cuka dari air kelapa. Air kelapa yang digunakan saat demonstrasi adalah air kelapa segar yang langsung diambil dari lokasi pembuatan kopra dimana air kelapa tersebut selama ini terbuang dengan sia-sia. 


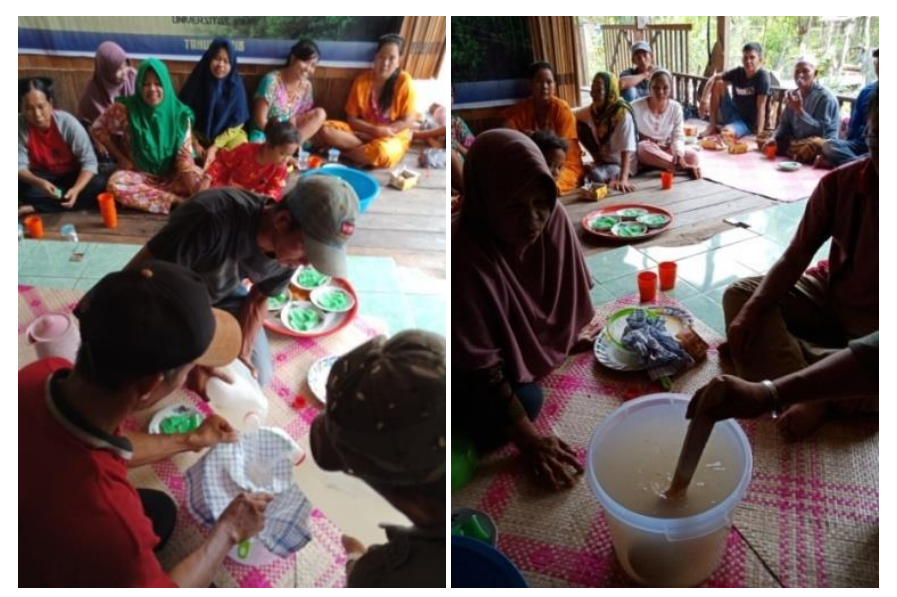

Gambar 4. Demonstrasi dan Praktek Pembuatan Asam Cuka

Anggota kelompok tani sangat antusias dengan kegiatan demonstrasi dan praktek pembuatan asam cuka ini dikarenakan mereka sangat senang bahwa air kelapa yang selama ini mereka buang karena tidak mengetahui manfaat ekonomi dari air kelapa ini. Asam cuka ini dapat digunakan oleh anngota kelompok tani khususnya dan masyarakat Dusun Bahagia Desa Tungkal I pada umumnya dalam memenuhi kebutuhan memasak mereka sehai hari karena asam cuka ini terbuat dari bahan alami yaitu air kelapa.

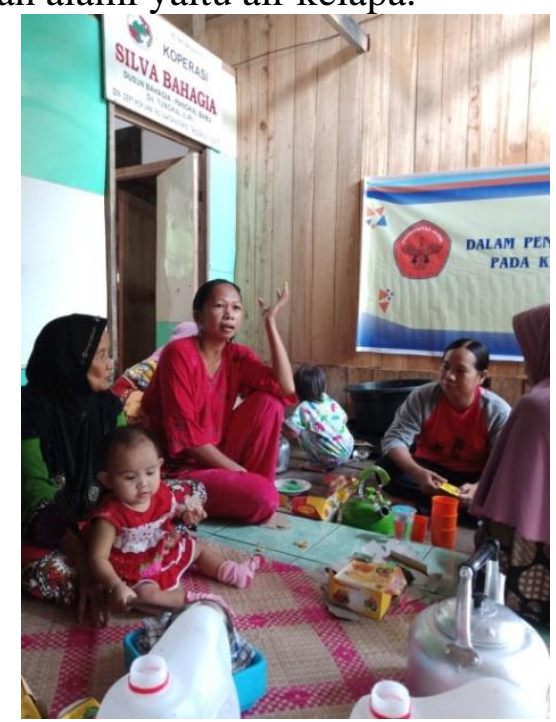

Gambar 5. Salah Satu Anggota Kelompok Tani Wanita RT. 08 Dusun Bahagia Sedang Mengajukan Pertanyaan

Dari kegiatan yang telah dilakukan, harapan dari anggota kelompok tani yaitu karena besarnya potensi air kelapa di Dusun Bahagia yang selama ini tidak termanfaatkan dengan baik dan sekarang anggota kelompok tani sudah mengetahui dan memiliki ketrampilan dalam membuat asam cuka dari air kelapa ini, selain akan dimanfaatkan untuk memenuhi kebutuhan sehari-hari anggota kelompok tani tersebut dalam memasak, anggota kelompok tani juga mengharapkan bimbingan dan pendampingan di dalam pengemasan serta penjualan asam cuka tersebut di luar dari lingkungan Dusun Bahagia.

Keinginan dari anggota kelompok tani tersebut sudah dipikirkan jauh hari oleh tim pengabdian pada masyarakat Fakultas Kehutanan Universitas Jambi. Melalui koperasi Sylva Bahagia yang telah dibentuk juga bersama antara Fakultas Kehutanan Universitas Jambi dan Anggota Kelompok Tani Bakau Lestari, tim pengabdian telah merancang di akhir kegiatan 
pengabdian pada masyarakat ini yaitu kegiatan penyuluhan pemahaman untuk meningkatkan pengetahuan masyarakat dalam aspek pengemasan dan pemasaran produk-produk yang telah dihasilkan dari kegiatan bina desa Fakultas Kehutanan Universitas Jambi (VCO, briket arang, cocopeat, asam cuka dan nata de coco).

Tim pengabdian pada masyarakat Fakultas Kehutanan Universitas Jambi memiliki harapan yang besar bahwa anggota kelompok tani khususnya dan masyarakat Dusun Bahagia Desa Tungkal I pada umumnya mampu memanfaatkan sumber daya alam yang tersedia yang sangat potensial di wilayah mereka yaitu buah kelapa dapat termanfaatkan secara keseluruhan dimana tidak ada satupun yang terbuang, dimulai dari daging kelapa yang diolah menjadi kopra, santan kelapa yang diolah menjadi VCO, sabut kelapa yang diolah menjadi briket arang, tempurung kelapa yang diolah menjadi arang dan briket arang, serta air kelapa yang diolah menjadi asam cuka dan nata de coco. Dengan demikan, anggota kelompok tani khususnya dan masyarakat Dusun Bahagia Desa Tungkal I pada umumnya memiliki kemandirian finansial yang dapat memenuhi dan meningkatkan kebutuhan ekonomi seharihari anggota kelompok tani khususnya dan masyarakat Dusun Bahagia Desa Tungkal I pada umumnya.

\section{KESIMPULAN DAN SARAN 5.1.Kesimpulan}

Dari kegiatan pengabdian pada masyarakat yang telah dilakukan dapat disimpulkan bahwa anggota kelompok tani Bakau Lestari dan kelompok tani wanita T.08 Dusun Bahagia sangat antusias di dalam pengolahan air kelapa ini menjadi asam cuka. Mereka telah memiliki kemampuan dan ketrampilan di dalam pembuatan asam cuka dari air kelapa tersebut.

\subsection{Saran}

Dari kegiatan ini dapat disarankan bahwa perlunya kerjasama dan dukungan dari pemerintah daerah setempat dalam melakukan bimbingan kepada masyarakat di dalam pengolahan dan pemasaran produk-produk yang dihasilkan dari kelapa dimulai dari buah, santan kelapa, sabut kelapa, tempurung kelapa, dan air kelapa dalam pemanfaatan secara maksimlal dari hasil perkebunan masyarakat yaitu buah kelapa yang akan meningkatkan perekonomian masyarakat Dusu Bahagia Desa Tungkal I pada khusunya dan masyarakat Kabupaten Tanjung Jabung Barat pada umumnya.

\section{UCAPAN TERIMA KASIH}

DIPA - PNBP Desa Binaan Fakultas Kehutanan Nomor : 042.01.2.400950/2018 Tanggal 05 Desember 2017; dan Surat Perjanjian Pelaksanaan pengabdian Kepada Masyarakat Nomor : 1440/UN21.17/PM/2018 Tanggal 23 April 2018

\section{DAFTAR PUSTAKA}

Bangun M. 2017. Komoditi Unggulan TanjabBar. Http://disbun.tanjabbar.go.id/. Diakses tanggal 6 Maret 2017. 
Indahyani T. 2003. Pemanfaatan Limbah Sabut Kelapa pada Perencanaan Interior dan Furniture yang Berdampak pada Pemberdayaan Masyarakat Miskin. urusan Desain Interior, Fakultas Komunikasi Multimedia, Bina Nusantara University.

Kemala N. 2015. Kajian Pendapatan dan Kontribusi Usahatani Kelapa (Cocos Nusifera) Terhadap Pendapatan Keluarga Petani di Kabupaten Tanjung Jabung Barat Provinsi Jambi. Jurnal Ilmiah Universitas Batanghari Volume 15 No.3 Tahun 2015 Hal 125132). 